\title{
Field Performance and Cost Economics of Popular Riding Type Mechanical Paddy Transplanters
}

\author{
P. Sudhakar Reddy*, P. Rajaiah, B. Ashwin Kumar, B. Laxman and A. Pramod Reddy \\ PJTSAU, Hyderabad-30, Telangana State, India \\ *Corresponding author
}

\begin{abstract}
A B S T R A C T
Rice is the staple food for Telangana, requires about 50 lakh tons annually to feed the population. Rice is being cultivated both in kharif and rabi season as one of the most important crop in Telangana. During the year, 2016-17 rice crop was grown in an area of about 12.2 lakh hectares and produced 47.6 lakh tons of rice with the productivity of 3902 $\mathrm{kg} / \mathrm{ha}$. Comparing the productivity of rice over other states, Telangana was in first place by crossing the leading states like Punjab, Haryana, Tamilnadu and AP imported selfpropelled transplanters have been using Telangana state for paddy transplanting to overcome the problem of labour scarcity during peak season of sowing. The field experiments were conducted in the farmer's fields in a total area of 60 ha during Kharif and Rabi 2017-18 in different villages of Telangana State with RNR -15048 and KNM-118 varieties in sandy clay loam soil to ascertain the performance of popular Kubota and Yanmarmodel paddy transplanters which are commercially available. The performance parameters evaluated were missing hills, floating hills, number of seedlings/hill, plant to plant spacing, seed rate, forward speed, field capacity, cost of operation and yield. It was seen that the farmers are willing to shift from conventional to machine transplanting due to shortage of labour, availability of imported mechanical transplanters and constant government support through various schemes. From the field results, the observed total average cost of operation of the transplanters was found to be Rs. 5,925/ha and Rs. 6,459/ha over manual transplanting with Rs.9500/ha and saving in cost over conventional method was Rs.3, 575/ha and Rs. 3,049/ha. The breakeven point and payback period of Kuboto and Yanmar transplanters were observed as 43.45\%, 2.3 years and 48.34\%, 2.6 years respectively without nursery raising machine. The yield observed was on par with conventional method with $7.5 \mathrm{t} / \mathrm{ha}$. The study showed that the mechanical transplanters will help the farmers and entrepreneurs in rice cultivation by reducing the human drudgery and labour problem.
\end{abstract}

\section{Introduction}

Rice is the world's most important crop and a staple food for more than half of the world's population. Rice ranks third after wheat and maize in terms of worldwide production.
About $90 \%$ of the world's rice (160 million ha of area with a production of 759 million tons of paddy) is grown and produced in Asia (FAO, 2017). Rice is the staple food for Telangana, requires about 50 lakh tons annually to feed the population. Rice is being 
cultivated both in kharif and rabi season as one of the most important crop in Telangana. During the year, 2016-17 rice crop was grown in an area of about 12.2 lakh hectares and produced 47.6 lakh tons of rice with the productivity of $3902 \mathrm{~kg} / \mathrm{ha}$. Comparing the productivity of rice over other states, Telangana was in first place by crossing the leading states like Punjab, Haryana, Tamilnadu and AP.

Traditionally, rice is sown manually by raising nursery separately in the field. The manual transplanting of rice has a tedious process and needs a manual labour of 250-300 man-h/ha. Manually operated drum seeders with separate cylindrical seed boxes to drill the pregerminated paddy seed on puddled soil also gained momentum for some time to overcome the transplanting drudgery. But the main concern with drum seeders was less capacity and suitable only for small scale farming community. Moreover, this method requires considerably higher seed rate and often exposes the seed to damage by birds and environment. Of late, the availability of manual labour for transplanting rice has decreased drastically due to migration of labour from villages to cities for more wageswhich has led to manual transplanting difficult. Mechanical transplanters developed in Japan, China, Korea and India have been using in the recent past for paddy transplanting by using mat nursery to overcome the labour problems. This paper illustrates the performance and cost economics of commercially available two popular paddy transplanters among the farming community.

Manjunatha et al., (2009) studied the performance of the 8-row self-propelled transplanter and the observed the field capacity, field efficiency and fuel consumption of the transplanter were 0.19 ha/hr, 78 per cent and 6.251/ha, respectively. The cost of mechanical transplanting was
Rs.789/ha as compared to Rs.1625/ha in case of manual transplanting. Grain yield in both manual and mechanical transplanting remained on par with mean grain yield of 53.77 and $54.01 \mathrm{q} / \mathrm{ha}$, respectively. Patil et al., (2016) evaluated the field performance of three types of paddy transplanters viz. Eight row self-propelled paddy transplanter (Yanji Shakti), Four row manual paddy transplanter (CRRI) and Two row hand cranked paddy transplanter. Speed of operation, Theoretical field efficiency, Actual field capacity, Field efficiency, Percentage of missing hills, Percentage of floating hills, Planting efficiency and other performance and operation related observations were taken as per the standard procedure and it was concluded that Self-propelled eight row transplanter (Yanji Shakti) is found to be better in performance on the basis of lesser percentage of missing hills (3.33\%), floating hills $(2.72 \%)$, better percentage of planting efficiency $95.18 \%$, field efficiency $(69.46 \%)$ and highest effective field capacity $(0.17$ ha/h). Murali et al., evaluated Self-propelled rice transplanter (Kubato Model) under different puddling conditions. The observed field efficiency, field capacity, and fuel consumption of the transplanter were, 62.96 $\%, 0.54 \mathrm{ha} / \mathrm{h}$ and $4.29 \mathrm{l} / \mathrm{h}$, respectively. The cost of operation of tractor operated disc puddler, rotovator and rotomixer was 484 $\mathrm{Rs} / \mathrm{h}, 538 \mathrm{Rs} / \mathrm{h}, 551 \mathrm{Rs} / \mathrm{h}$ and cost of operation of transplanter is $965 \mathrm{Rs} / \mathrm{h}$. Compared to manual transplanting of paddy the machine was found to be farmer friendly and feasible in terms of time, money and labour requirement. Senthilkumar and Ravindra Naik (2016) Studied the adoption of mechanical rice transplanters through custom It was observed that there is a paradigm shift from manual rice transplanting to mechanical rice transplanting, basically due to increased farm power availability, reduction in working manpower, import of mechanical rice transplanter and constant government support through various 
schemes. It is observed that for the 8 row Yanji rice transplanter, the break even hours of usage is 100 per annum. The total cost of operation of the machine works out to Rs. 200 $\mathrm{h}$, where in Yanmar rice transplanter, it was found that the break even hours of usage is 550 per annum. The total cost of operation of the machine works out to Rs. $400 / \mathrm{h}$. Case study clearly depicts that custom hiring services will help both farmers and entrepreneur in rice cultivation

\section{Materials and Methods}

Two self-propelled paddy transplanters of Kubota (6-row, Petrol) and Yanmar (6-row, diesel) were used for transplanting with mat type seedlings and cost economics was estimated. These transplanters consists of 17 $\mathrm{hp}$ and $13 \mathrm{hp}$ water cooled petrol and diesel engine powered with six trays seedlings racks are provided with power steering (Fig. 2). In these transplanters adjustments involved are number of seedlings per hill, depth of transplanting and hill to hill spacing. In both the transplanters, during transplanting depth of transplanting were maintained from $2-5 \mathrm{~cm}$ and row to row spacing is $30 \mathrm{~cm}$. The specifications of self-propelled paddy transplanters are furnished (Table 1).

The nursery was raised on trays with automatic nursery raising machine in the farmers field. The automatic nursery raising machine consists of two motors of $0.33 \mathrm{hp}$, four hoppers for filling trays with bottom soil, seed feeder, water and top soil. The average quantity of seed required for each tray was about 120-150 gram/tray with a labour requirement of 6 persons. The machine output capacity was 600 trays/hr. For transplanting one acre, around 75-80 trays of nursery was utilized (Fig. 1).

The field experiments were conducted in total area of 60 ha during Kharif and Rabi 2017-18 in different villages of Pulkalmandal of Sangareddy district, Telangana State with RNR 15048 and KNM-118 varieties in sandy clay loam soil.

\section{Field preparation of mechanical transplanting}

The tractor drawn cultivator and rotopuddler was used for first puddling operation 15 days before transplanting and followed by second puddling operation was done with rotopuddler 2 to 3 days before transplanting (Fig. 3).

\section{Missing hills}

It is the ratio of the total number of hills without seedlings to the total number of hills expressed in percentage and it can be calculated by the following equation.

$\mathrm{H}_{\mathrm{pm}}=\frac{H_{m}}{H_{t}} \times 100$

Where,

$\mathrm{Hpm}=$ Percent missing hills, per cent

$\mathrm{Hm}=$ Total number of missing hills in the sampling area

$\mathrm{Ht}=$ Total number of hills in the sampling area

\section{Floating hills}

It is the ratio of the total number of hills floating after transplanting to the total number of hills expressed in percentage and it can be calculated by the following equation.

Floating Hills $(\%)=\frac{F H}{T N H} \times 100$

Where, 
$\mathrm{FH}=$ Percent floating hills, per cent

$\mathrm{FH}=$ number of floating hills, $\mathrm{m}^{2}$

$\mathrm{TNH}=$ Total number of hills in sampling area, $\mathrm{m}^{2}$

\section{Cost economics}

Detailed economics of cultivation for conventional and mechanical rice transplanting was worked out in terms of the nursery raising and maintenance cost, cost of initial soil bed preparation, puddling, cost of operation for self-propelled rice transplanter for mechanical rice transplanting, labour charges. The following are parameters were taken in to consideration for estimating the cost economics of transplanting methods.

\section{Breakeven point}

The breakeven point is the point at which the gains equal to the losses. A break -even point defines when an investment will generate a positive return. There is no profit made or loss incurred at the breakeven point.

In fact, the breakeven point is the lower limit of profit when prices are set and margins are determined (IS-9164:1979).

$\mathrm{BEP}=\mathrm{FC} /(\mathrm{CF}-\mathrm{C})$

Where,

$\mathrm{BEP}=$ Breakeven point, $\mathrm{h} /$ year

$\mathrm{FC}=$ Annual fixed cost, Rs/year

$\mathrm{CF}=$ Custom fee, $\mathrm{Rs} . / \mathrm{h}$

$\mathrm{C}=$ operating cost, $\mathrm{Rs} / \mathrm{h}$

$\mathrm{CF}=1.25 \mathrm{x}(\mathrm{C}+0.25 \mathrm{C})$

\section{Payback period}

The Payback period is defined as the length of time required to recover an initial investment through cash flows generated by the investment.
$\mathrm{PBP}=\mathrm{IC} / \mathrm{ANP}$

Where,

PBP $=$ Payback period, year

IC = Initial cost of machine, Rs.

$$
\mathrm{ANP}=(\mathrm{CF}-\mathrm{C}) \mathrm{AU}
$$

Where,

$\mathrm{ANP}=$ Annual net profit

$\mathrm{AU}=$ Annual utility, hr/year

$\mathrm{AU}=\mathrm{AA} \times \mathrm{EC}$

Where,

$\mathrm{AA}=$ Average annual use, $\mathrm{h} /$ year

$\mathrm{EC}=$ Effective capacity of machine, ha/h

\section{Results and Discussion}

\section{Performance of transplanters}

The transplanting was done in 60 ha of farmer's fields with two types of selfpropelled paddy transplanters in Kharif and Rabi seasons with different varieties at $30 \mathrm{~cm}$ row to row spacing and plant to plant was varied from $12-14 \mathrm{~cm}$. The seed rate was $30-$ $38 \mathrm{~kg} / \mathrm{ha}$ and the germination percentage was $99 \%$. The effective field capacity of the transplanters observed was $0.35 \mathrm{ha} / \mathrm{hr}$. The total cost of operation per hectare observed for self-propelled transplanters was Rs.59256459/- against the conventional method of Rs.9500/- (Table 2).

\section{Cost economics of transplanters}

The cost economics of two self-propelled transplanters was estimated based on the field performance. The cost of the Kubotoa nd Yanmar riding type transplanters were considered as Rs. 10, 00,000/- and 15, $00,000 /-$ respectively. The average number of working hours per year assumed as 500 hours. 
Fig.1 Nursery raised with automatic tray type nursery raising machine
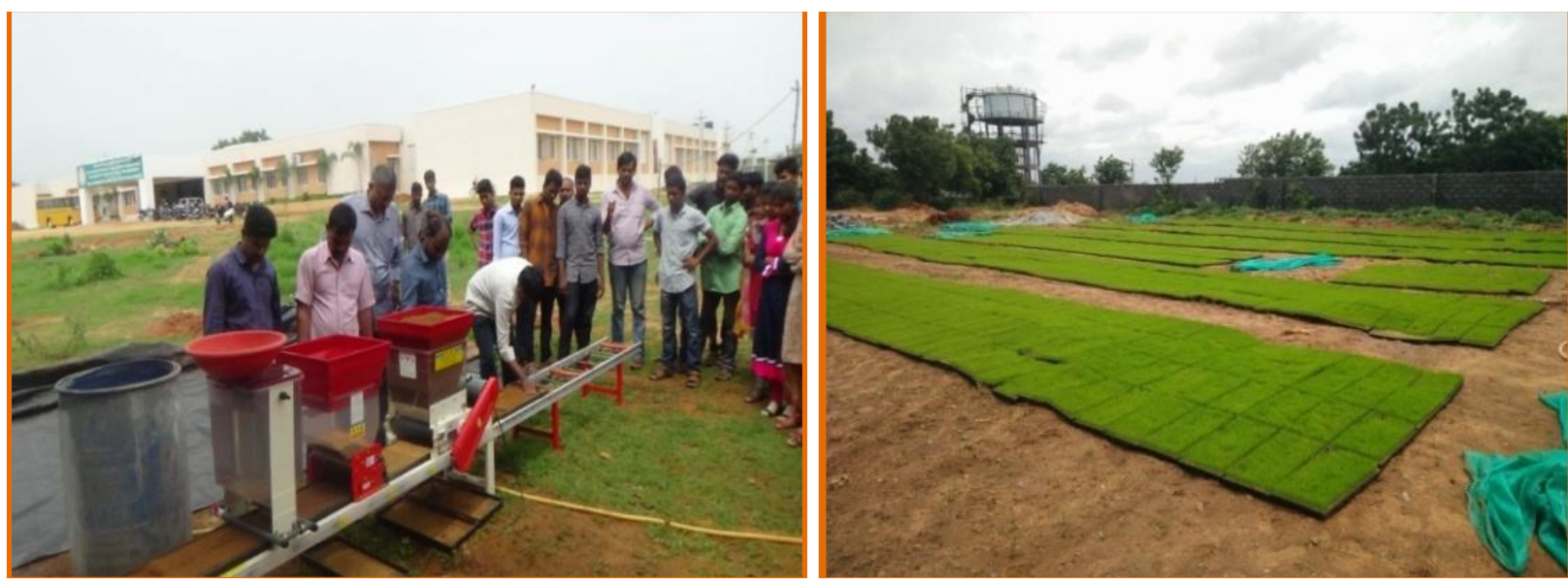

Fig.2 Kubota and Yanmar paddy Transplanters
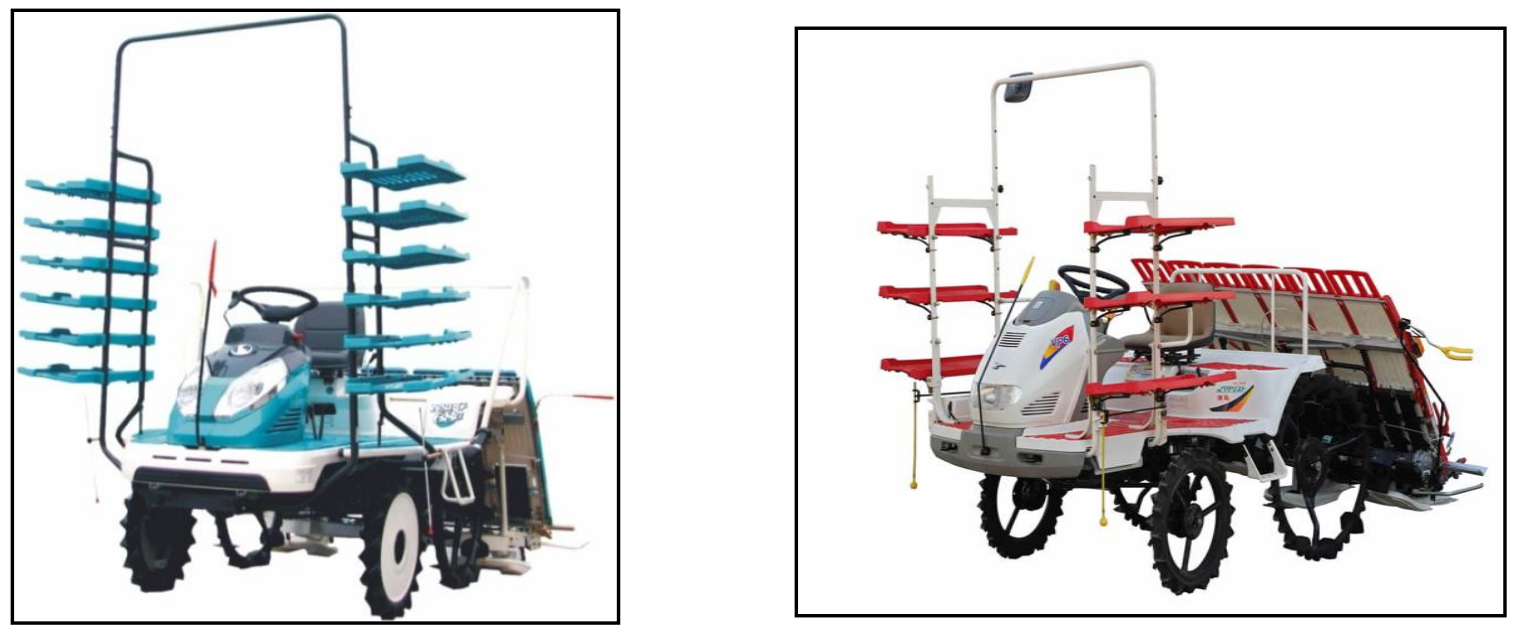

Fig.3 Rotopuddler

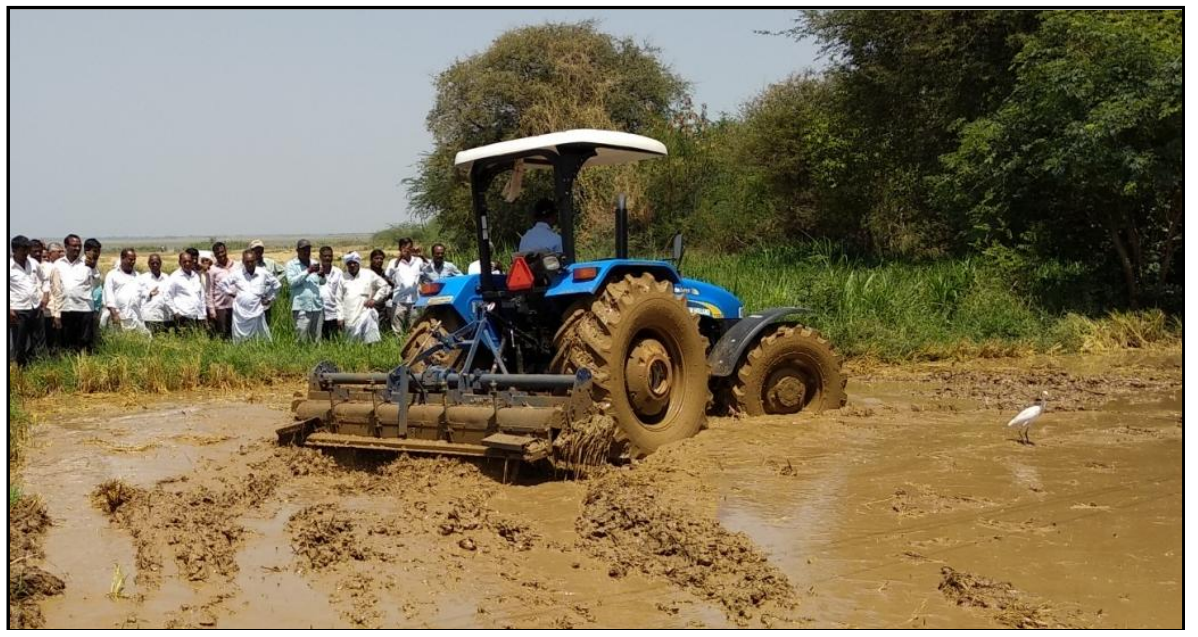


Table.1 Specifications of Self-propelled paddy Transplanters

\begin{tabular}{|c|c|c|c|}
\hline S. No & Parameter & \multicolumn{2}{|c|}{ Details } \\
\hline 1 & Type & Riding type & Riding type \\
\hline 2 & Make & Kubota & Yanmar \\
\hline 3 & Model & NSPU - 68C & VP - 6D \\
\hline 4 & Overall dimensions, $\mathrm{mm}$ & $3000 \times 2210 \times 2570$ & $3090 \times 2135 \times 1560$ \\
\hline 5 & Weight, kg & 590 & 600 \\
\hline 6 & Unit price, Rs. & $10,00,000$ & $15,00,000 /-$ \\
\hline 7 & Power source & $\begin{array}{l}8.5 \mathrm{~kW} \text { Water-cooled, 4-cycle, } 2- \\
\text { cylinder OHC gasoline engine }\end{array}$ & $\begin{array}{l}9.2 \mathrm{~kW} \text {, water cooled, } 4 \text {-stroke, } \\
\text { petrol engine }\end{array}$ \\
\hline 8 & Rated width, mm & 1800 & 1800 \\
\hline 9 & Number of row & 6 & 6 \\
\hline 10 & Row spacing, mm & 300 & 300 \\
\hline 11 & Distance between hills in a row, $\mathrm{mm}$ & $120-210$ & 130 to 210 \\
\hline 12 & Seeding tray width, mm & 280 & 280 \\
\hline 13 & Seeding tray height, $\mathrm{mm}$ & 20 to 25 & 20 to 25 \\
\hline 14 & Power transmission system & $\begin{array}{l}\text { Synchromesh gear box with two } \\
\text { speeds and one reverse speed }\end{array}$ & $\begin{array}{l}\text { Synchromesh gear box with two } \\
\text { speeds and one reverse speed }\end{array}$ \\
\hline
\end{tabular}

Table.2 Field performance of Kubota and Yanmar paddy transplanters

\begin{tabular}{|c|c|c|c|c|}
\hline \multirow[t]{2}{*}{ S. No } & \multirow[t]{2}{*}{ Parameters } & \multirow{2}{*}{$\begin{array}{l}\text { Farmers's } \\
\text { practice }\end{array}$} & \multicolumn{2}{|c|}{ Paddy transplanters } \\
\hline & & & $\begin{array}{l}\text { Kuboto Riding type } \\
\text { (Petrol) }\end{array}$ & $\begin{array}{l}\text { Yanmar Riding type } \\
\text { (Diesel) }\end{array}$ \\
\hline 1 & Methods of nursing raising & Conventional & Tray type nursery & Tray type nursery \\
\hline 2 & Seeding age, days & $20-25$ & $20-25$ & $20-25$ \\
\hline 3 & Effective working width, mm & -- & 1800 & 1800 \\
\hline 4 & Type of soil & Sandy clay loam & Clay loam & Sandy clay loam \\
\hline 5 & Type of variety & RNR 15048 & RNR 15048 & $\begin{array}{c}\text { RNR } 15048 \text { and KNM- } \\
118\end{array}$ \\
\hline 6 & Row to row spacing, mm & $200-400$ & 300 & 300 \\
\hline 7 & Working depth, mm & $30-50$ & $20-50$ & $20-50$ \\
\hline 8 & Planting speed, $\mathrm{m} / \mathrm{s}$ & 0.10 & 0.65 & 0.65 \\
\hline 9 & Number of seedlings/hill & $4-5$ & $3-5$ & $4-6$ \\
\hline 10 & Plant to plant spacing, $\mathrm{mm}$ & $90-150$ & $130-140$ & $120-140$ \\
\hline 11 & Seed rate, $\mathrm{kg} / \mathrm{ha}$ & $60-75$ & $30-38$ & $30-38$ \\
\hline 12 & Speed, Kmph & -- & 2.72 & 2.68 \\
\hline 13 & Effective field capacity, ha/h & 0.055 & 0.35 & 0.36 \\
\hline \multirow[t]{2}{*}{14} & Number of missing hills, $\%$ & 0 & 0.5 & 0.4 \\
\hline & Floating hills, $\%$ & 0 & 0.2 & 0.2 \\
\hline 15 & Germination percentage, $\%$ & -- & 99.3 & 99.4 \\
\hline 16 & Field efficiency, \% & -- & 71.23 & 74.62 \\
\hline 17 & $\begin{array}{l}\text { Labour requirement, man-h/ha } \\
\text { (Transplanting) }\end{array}$ & 18 & 3 & 3 \\
\hline 18 & Fuel consumption, $1 / \mathrm{h}$ & -- & 3.5 & 3.0 \\
\hline 19 & Cost of operation, Rs./h & -- & $873 /-$ & 1076/- \\
\hline 20 & Cost of operation, Rs./ha & $6500 /-$ & $2156 /-$ & $2690 /-$ \\
\hline 21 & Cost of operation for nursery raising, Rs./ha & $3000 /-$ & $3,769 /-$ & $3,769 /-$ \\
\hline 22 & Total cost of operation, Rs./ha & $9500 /-$ & $5925 /-$ & $6459 /-$ \\
\hline 23 & Saving in cost, Rs/ha & -- & $3575 /-$ & $3041 /-$ \\
\hline 24 & Yield, t/ha & $6.8-7.5$ & 7.5 & $7.5-8$ \\
\hline
\end{tabular}


Table.3 Cost economics of two self-propelled paddy transplanters

\begin{tabular}{|r|l|c|c|}
\hline $\begin{array}{r}\text { S. } \\
\text { No }\end{array}$ & \multicolumn{1}{|c|}{$\begin{array}{c}\text { Description } \\
\text { Kuboto Riding type } \\
\text { (Petrol) }\end{array}$} & $\begin{array}{c}\text { Yanmar Riding type } \\
\text { (Diesel) }\end{array}$ \\
\hline 1. & Cost of machine, (Rs.) & \multicolumn{2}{|c|}{ Average Cost } \\
\hline 2. & Number of working hours per year & 500 & $15,00,000 /-$ \\
\hline 3. & Fuel cost, (Rs/h) & 266 & 500 \\
\hline 4. & Custom hiring cost, (Rs/h) & 1365 & 238 \\
\hline 5. & Breakeven point, (\%) & 43.45 & 1681 \\
\hline 6. & Payback period, (years) & 2.3 & 48.34 \\
\hline 7. & Annual utility, (ha) & 170 & 2.6 \\
\hline
\end{tabular}

Fuel cost, total operating cost and custom hiring cost of the Kuboto riding type transplanter were, Rs. 266, Rs. 873 and Rs. 1365 and Yanmarriding type transplanter were 500, Rs. 238, Rs. 1076 and Rs. 1681 respectively.

The average breakeven point, payback period and annual utility of the Kuboto riding type transplanter were $43.45 \%, 2.3$ and 170 ha and Yanmar riding type transplanter were $48.34 \%$, 2.6and 170 ha respectively (Table 3 ).

Two popular riding types of rice transplanters selected in Telangana State for evaluating their performance in the farmers fields.

It was observed that the farmers are willing to shift from conventional to machine transplanting due to shortage of labour, availability of imported mechanical transplanters and constant government support through various schemes.

The yield observed was on par with conventional method of transplanting (7.5 t/ha).

The popularization of mechanical transplanting can be boosted up further among the farming community through custom hiring system.

\section{References}

Behera BK, Varshney BP, Swain S. Influence of seedling mat characteristics on the performance of self-propelled rice transplanter. Agricultural Engineers Today. 2007; 31(1):1-6.

Behera BK, Varshney, BP, Goel AK. Effect of puddling on puddled soil characteristics and performance of selfpropelled transplanter in rice crop. International Journal of Agricultural and Biological Engineering. 2009; 10(5):1-18.

Chaudhary VP, Varshney BP. Performance evaluation of self-propelled rice transplanter under different puddled field conditions and sedimentation periods. Agricultural Mechanization in Asia. 2003; 34(2):23-33.

FAO of the United Nations, Rice market monitor. 2017; Vol 10 (2).

IS-9164-17979-Guide for estimating cost of farm machinery operation. Indian standard institute. Govt. of India, New Delhi, 1-17.

Manjunatha, MV, BG Masthana Reddy, SD Shashidhar and VR Joshi. 2009. Studies on the performance of self-propelled rice transplanter and its effect on crop yield. Karnataka Journal of Agricutural Sciences 22(2):385-387. 
Murali, M., M. Anantachar, K. V. Prakash, Sunil Shirwaland U. Satishkumar., Performance and Evaluation of Six Row Self-propelled Paddy Transplanter under Different Puddling Methods. Indian Journal of Science and Technology, Vol 9(47)

Patil S. B., Shahare P. U and V. V. Aware. Study of different commercially available paddy transplanters in konkan region of Maharashtra state: International Journal of Agricultural Science and Research. 2016; Vol. 6, Issue 6, 247-252.
Senthilkumar T. and Ravindra Naik, Study of Adoption of Mechanical Rice Transplanters through Custom Hiring in Tamil Nadu a Case Study: Journal of Rice Research 2016, Vol 9 No. 1-35.

Ved Prakash Chaudhary and Varshney, B. P. 2003, Performance evaluation of selfpropelled rice transplanter under different puddle field conditions and sedimentation periods. Agril. Mechanization in Asia, Africa and Latin America (AMA), 34: 23-33.

\section{How to cite this article:}

Sudhakar Reddy, P., P. Rajaiah, B. Ashwin Kumar, B. Laxman and Pramod Reddy, A. 2018. Field Performance and Cost Economics of Popular Riding Type Mechanical Paddy Transplanters. Int.J.Curr.Microbiol.App.Sci. 7(10): 2867-2874. doi: https://doi.org/10.20546/ijcmas.2018.710.334 